\title{
MINERAL OIL PARAFFINS IN JUTE BAGS AND COCOA BUTTER
}

\author{
J. Serra Bonvehía* and F. Ventura Coll ${ }^{b}$ \\ ${ }^{a}$ Research \& Development, Nederland Co., PO Box 34, 08890 Viladecans, Barcelona. Spain \\ ${ }^{b}$ Business Development, Mondelēz International/Kraft Foods Co., 08170 Montornès, Barcelona. Spain
}

(Received: 16 April 2012; accepted: 14 November 2012)

\begin{abstract}
Jute bags and cocoa butter (CB) were analysed by gas chromatography (GC-FID/MS) to detect and quantify mineral oil saturated hydrocarbons (MOSH). Extraction clean-up on silica gel SPE $(10 \mathrm{~g} / 60 \mathrm{ml})$ was developed, as a unique sample preparation step for the determination of linear and branched $n$-alkanes in the range $\mathrm{C}_{14}$ to $\mathrm{C}_{31}$. The size of CB sample (500 mg) was sufficient for the detection of batching oil at levels of $2 \mathrm{mg} \mathrm{kg}^{-1}$, with satisfactory recovery and repeatability. MOSH from batching oil form a hump of unresolved components and the shape reflect balanced molecular-mass distribution between even and odd carbon atoms (from $\mathrm{C}_{14}$ to $\mathrm{C}_{22} n$-alkanes), expressed with the Carbon Preference Index ( $\mathrm{CPI}=\sum$ odd homologs $/ \sum$ even homologs). Contaminated raw $\mathrm{CB}$ extracted from cocoa beans, transported and stored in jute bags during 2000 and 2001, showed MOSH (average $42 \mathrm{mg} \mathrm{kg}^{-1}$ ). However, only the $7.5 \%$ of the samples analysed of deodorized CB from 2007 to 2009 contained MOSH $<36 \mathrm{mg}$ $\mathrm{kg}^{-1}$. High CPI values $(>1.26)$ were attributed to natural hydrocarbons with a strong predominance of odd-numbered paraffins, situated between $\mathrm{C}_{22}$ and $\mathrm{C}_{31} n$-alkanes (average $31.7 \pm 5.37 \mathrm{mg} \mathrm{kg}^{-1}$ ). The results confirmed that MOSH components below $n-\mathrm{C}_{20}$ were fully eliminated by the deodorization process.
\end{abstract}

Keywords: cocoa butter, paraffins, batching oil, jute bags, food safety

Cocoa butter (CB) consists of symmetrical triglyceride groups and complex mixtures of minor compounds (LIPP \& ANKLAM, 1998). The minor compounds include saturated and unsaturated hydrocarbons $\left(\mathrm{HC}^{\prime} \mathrm{s}\right)$, primarily $n$-alkanes, mainly with odd numbered carbon atoms, ranging between $\mathrm{C}_{21} \mathrm{H}_{44}$ and $\mathrm{C}_{35} \mathrm{H}_{72}$, and olefins ( $n$-alkenes), primarily in the ranges $\mathrm{C}_{16} \mathrm{H}_{32}-\mathrm{C}_{20} \mathrm{H}_{40}$ and $\mathrm{C}_{25} \mathrm{H}_{50}-\mathrm{C}_{30} \mathrm{H}_{60}$ (LIPP \&ANKLAM, 1998; WAGNer et al., 2001a). If only saturated hydrocarbons analysis is desired, olefins can be previously eliminated using silver ion chromatography. In contrast to the natural alkanes, mineral oil paraffins (MOSH) are saturated $n$-alkanes, containing highly isomerised isoalkanes and cyclic components in enormous numbers, which rule out complete resolution by GC (WAGNER et al., 2001b). In fact, MOSH chromatograms usually show a broad hump of unresolved material, which is referred as an 'unresolved complex mixture' (UCM). In the case of MOSH from batching oil, this hump ranges from $n-\mathrm{C}_{14}$ to beyond $n-\mathrm{C}_{22}$, with a number of carbon atoms balanced between even and odd-numbered components, which could be expressed as Carbon Preference Index (CPI $=\sum$ odd homologs $/ \sum$ even homologs) (VolKMAN et al., 1992). In general, mineral oil fractions can be classified as types A, B, or C. Type A groups diesel and heating oil, both characterized by the high presence of $n$-alkanes ranging from $n$ - $\mathrm{C}_{8}$ to about $n-\mathrm{C}_{25}$, and kerosene similar to diesel oil, but only reaching to about $n-\mathrm{C}_{18}$. Type $\mathrm{B}$ group gas oils (high vacuum distillates with a Gaussian type volatility distribution from $n-\mathrm{C}_{10}$ to $n-\mathrm{C}_{15}$ ), paraffin oils also known as white oils (commonly centred at the retention time of $\mathrm{C}_{21}-\mathrm{C}_{24}$ $n$-alkanes), lubricant oils (e.g. motor oils) at $\mathrm{C}_{28}-\mathrm{C}_{32}$, and hydraulic oils at $\mathrm{C}_{23}-\mathrm{C}_{30}$. Type $\mathrm{C}$ groups poly-alpha-olefins (PAOs), coming from condensates of unsaturated mineral oil

\footnotetext{
* To whom correspondence should be addressed.

Phone: +34 (93) 750-8211; fax: +34 (93) 753-2607; e-mail: serrjosep@gmail.com
} 
products, in $\mathrm{GC}$ forming a hump of unresolved isoalkanes reaching from linear $\mathrm{C}_{25}$ to $\mathrm{C}_{45}$ $n$-alkanes (WAGNER et al., 2001b).

When analysing these compounds by GC the resulting chromatogram shows discrete peaks for type A, whereas by $\mathrm{B}$ and $\mathrm{C}$ types present a hump of unresolved peaks. Often $n$-alkanes disappear (by microbial degradation), leaving behind only the branched alkanes (isoalkanes) and aromatic components, which form a 'UCM' in the GC chromatogram. Furthermore, isoprenoid alkanes (pristane and phytane) and triterpenoid alkanes (hopanes) are common constituents of most mineral oils, and thus are often considered as good indicators of petroleum contamination (Volkman et al., 1992; Populin et al., 2004). Pristane (tetramethyl pentadecane) can be present as a direct input from the lipids of certain zooplankton, whereas phytane (tetramethyl hexadecane) occurs in the lipids of Archaebacteria (methanogen bacteria), and thus can be abundant in anaerobic petroleum sediments. Isoalkanes are undegradable by bacteria and built up in the nature.

In 1989 it was found that almost all hazelnuts contained MOSH ranging from $\mathrm{C}_{14}$ to $\mathrm{C}_{22}$ $n$-alkanes. The presence of these compounds was related to the high boiling mineral oil applied to jute and sisal fibre bags (used to manufacture and storage), of around $1-1.5 \mathrm{~kg}$ weight for around $50 \mathrm{~kg}$ of content (jute batching oil (JBO) contains about $94.8 \%$ unsaponifiable matters; boiling point $270-450{ }^{\circ} \mathrm{C}$ ). In the application of conventional JBO emulsion $(20 \%$ on the weight of fibre, owf) mineral paraffins rose to $4 \%$ oil in the fibre and in the application of $30 \%$ owf emulsion the value rose to $6.0 \%$ oil in the fibre (DiLruBA et al., 2010). At the end of the manufacturing process, bags were aired for months to remove the most volatile fraction of JBO. Foods transported and stored in these bags, such as hazelnuts, cocoa beans, linseeds, coffee beans, and rice, were found to be contaminated with MOSH at 10-100 mg kg-1 (GroB et al., 1991, 1992).

The US Food and Drug Administration (FDA) set a limit of $10 \mathrm{mg} \mathrm{kg}^{-1}$ for incidental food contamination by specified lubricating oil (H1 food grade oil, being free of aromatic components) (US FDA, 1987). After this, some edible oil batches were found to be contaminated with more than $10 \mathrm{mg} \mathrm{kg}^{-1}$ of MOSH, with the maximum concentration found around $1000 \mathrm{mg} \mathrm{kg}^{-1}$ (McGill et al., 1993; Moret et al., 2003; Fiorini et al., 2008). High concentration of MOSH was reached in edible oil adulterated with mineral oil, such as some Ukrainian sunflower oil batches in 2008 (BIEDERMANN \& GROB, 2009; FisELER \& GROB, 2009).

In 1995, EU-Scientific Committee on Food (SCF), the predecessor of the European Food Safety Authority (EFSA), defined the "high-viscosity mineral oil" by a minimum viscosity, a maximum of 5\% components with a boiling point below that of the $n$-alkane $\mathrm{C}_{25}$ and an average molecular mass of no less than $480 \mathrm{Da}\left(\mathrm{C}_{34}\right.$-paraffins, $\left.478 \mathrm{Da}\right)$ (TennANT, 2004; EFSA, 2012). For refined paraffinic waxes, derived from petroleum-based or synthetic hydrocarbon feedstocks, the specifications were: average molecular weight not less than 350 , viscosity at $100{ }^{\circ} \mathrm{C} \min .2 .5 \mathrm{~mm}^{2} \mathrm{~s}^{-1}$, content of hydrocarbons with carbon number less than 25 , not more than $40 \%$ (w/w) (EFSA, 2012). These decisions were based on the fact that human body absorption of alkanes with carbon number above $\mathrm{C}_{35}$ is negligible. More recently, EFSA stated that MOSH from $\mathrm{C}_{16}$ to $\mathrm{C}_{35} n$-alkanes may accumulate and cause microgranulomas in several tissues, including lymph nodes, spleen, and liver (EFSA, 2012). Acceptable daily intakes had been previously established by the Joint FAO/WHO Expert Committee on Food Additives (JEFCA) as 0-20 $\mathrm{mg} \mathrm{kg}^{-1}$ body weight (b.w.) for high viscosity mineral oil, 0-10 $\mathrm{mg} \mathrm{kg}^{-1}$ b.w. for low and medium density class I mineral oil, and $0-0.01 \mathrm{mg} \mathrm{kg}^{-1} \mathrm{~b}$.w. for low and medium density class II and class III mineral oil (JECFA, 1995). 
On the other hand, several papers described automatic on-line LC-Solvent EvaporationGC-FID for the analysis of mineral oil distinguishing between mineral paraffins and natural paraffins of plant origin (mainly odd-numbered n-alkanes) (DrOz\& GROB, 1997). Chromatograms usually showed the presence of unsolved material in contaminated samples indicating no complete resolution and identification of components. As GC-MS technique was not able to confirm the unsolved peaks, flame ionization detection (FID) was selected, using the corresponding standards. However, the low sensitivity that exhibited FID determined that a better pre-separation and larger injection of fat would be required in order to achieve a detection limit of mineral oil of approximately $1 \mathrm{mg} \mathrm{kg}^{-1}$ (Droz \& GroB, 1997). In that sense, the use of sample (CB) clean-up through a new sep-pak of silica gel $(10 \mathrm{~g} / 60 \mathrm{ml})$ considerably reduced interferences, obtaining higher fat retention without detecting fat breakthrough (triglycerides) in the MOSH and faster elution, presenting satisfactory and comparative sensitivity related to automated on-line systems using GC-FID (BASTOw et al., 2007; FIORINI et al., 2010). When necessary, confirmation of natural paraffins in the uncontaminated samples could be achieved by mass spectrometry detection (GC-MS). This technique may also be used to extract and quantify marker components, such as steranes and hopanes, considered as proof of mineral origin (PoPULIN et al., 2004).

The aim to assess the impact of MOSH in commercial CB and our major concern on food safety led us to carry out this work, in order to better determine the contamination origin and properly quantify its possible occurrence during storage and transport of cocoa bean products.

\section{Materials and methods}

\subsection{Materials}

The samples were selected from a cocoa manufacturing factory (Nederland Co., Spain), from different periods (2000-2001; 2007 to 2009), according to statistic guidelines for analysis of sample inspection (GRYNA et al., 2005). The experimental material was composed by: a) 40 samples of raw CB extracted from cocoa beans (fermented and dried), stored and transported in jute bags from different origins (Ghana, Cameroon, Ivory Coast, and Brazil); b) 40 samples of commercial expeller CB obtained from roasted cocoa beans (before roasting, the cocoa beans were passed through infra-red light to separate the shell from the kernels, broken, and then sieved) and deodorized by steam at $140{ }^{\circ} \mathrm{C}$ under vacuum for $3 \mathrm{~h}$; and c) 40 samples of jute bags used for transporting and storing cocoa beans to check the initial contamination. The samples were maintained at room temperature $\left(20-25^{\circ} \mathrm{C}\right)$ before being analysed. The samples were analysed at least in duplicate and the reported values were averages.

\subsection{Chemicals and standards}

Residue analysis-grade chloroform, $n$-hexane, and eicosane (purity, 99\% minimum) were supplied from Sigma Aldrich (St. Louis, MO, USA). Eicosane $\left(\mathrm{C}_{20} \mathrm{H}_{42}\right)$ was used as external standard. The standard aliphatic hydrocarbons (ASTM D5442 $\mathrm{C}_{16}$ to $\mathrm{C}_{44}$ ) were obtained from Supelco (Bellefonte, PA, USA). Jute batching oil IJO Standard 98/01 was obtained from the International Jute Study Group (Dhaka, Bangladesh). Certified cocoa butter IRMM-801, free of mineral oil, was purchased from the Institute for Reference Materials and Measurements (Geel, Belgium). Silica gel SPE cartridge $(10 \mathrm{~g} / 60 \mathrm{ml})$ (sep-pak spe-ed AP-5107) was supplied by Applied Separations (Allentown, PA, USA). 


\subsection{Sample preparation of jute bags and raw cocoa butter}

After removing the shells of cocoa beans, raw CB was extracted manually with $n$-hexane by shaking for $30 \mathrm{~min}$. The mixture was filtered through Whatman $2 \mathrm{~V}$ paper (Sigma-Aldrich, St. Louis, MO, USA) and the solvent evaporated with a rotary evaporator under vacuum $\left(35^{\circ} \mathrm{C}\right)$ to dryness.

Ten samples of jute bag in pieces ( $5 \mathrm{~g}$ each) were immersed in $50 \mathrm{ml} n$-hexane overnight (12 h minimum) and extracted for $30 \mathrm{~min}$ in an ultrasonic bath (room temperature). After collecting and filtering the extracts, the solvent was evaporated with a rotary evaporator under vacuum $\left(35^{\circ} \mathrm{C}\right)$ to dryness. The residue was weighed and solved in $5 \mathrm{ml} n$-hexane. Finally $1 \mu \mathrm{l}$ was injected into the chromatographic system. Figure 1 shows a typical GC-FID chromatogram of jute batching oil, with MOSH peaks on top of the hump.

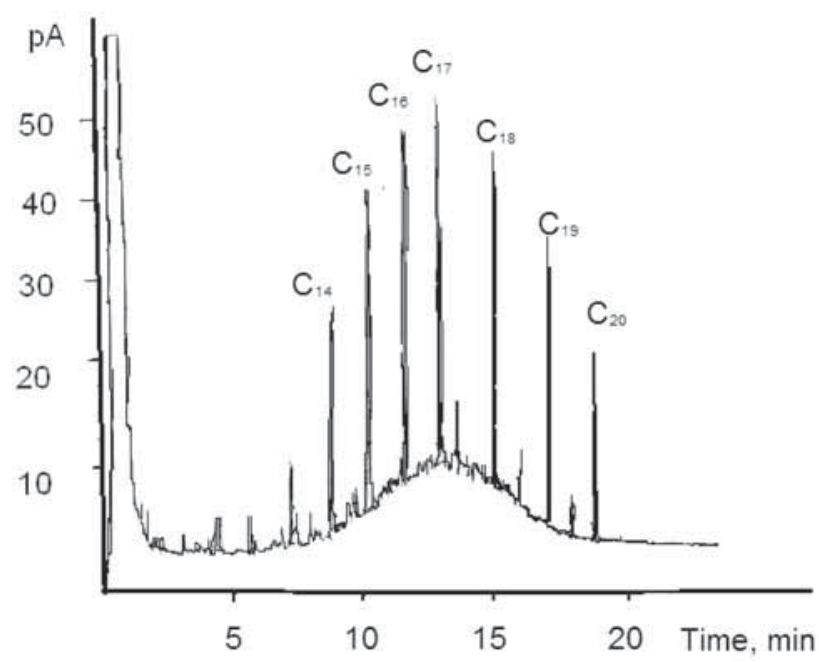

Fig. 1. GC/FID chromatogram of jute batching oil

\subsection{MOSH isolation from cocoa butter}

Sample clean-up was performed by using SPE cartridges of silica gel. About $5 \mathrm{~g}$ of CB were weighed into a $50 \mathrm{ml}$ volumetric flask and diluted to volume with $n$-hexane. Later, $5 \mathrm{ml}$ of the sample solution was loaded onto $10 \mathrm{~g} / 60 \mathrm{ml}$ silica SPE cartridge (spe-ed AP-5107) previously washed with $20 \mathrm{ml}$ of dichloromethane, dried completely by vacuum, and conditioned with $20 \mathrm{ml} n$-hexane. MOSH were eluted with $35 \mathrm{ml} n$-hexane. The first $5 \mathrm{ml}$ were discarded. Then the following fraction was collected in a vial and concentrated until dryness in a rotary evaporator under vacuum at a maximum temperature of $35^{\circ} \mathrm{C}$. The remaining aliphatic MOSH residue was solved in an accurately measured volume of $1 \mathrm{ml} n$-hexane and $1 \mu \mathrm{l}$ injected into the chromatographic system.

\subsection{Olefins pre-separation}

In the case of unsaturated hydrocarbons (olefins) that could be misinterpreted as mineral paraffins due to the low resolution, the use of a second column of silica gel coated with silver 
nitrate is recommended (10\% silver nitrate coated silica gel; 21319-U Supelco, Bellefonte, PA, USA) (CERT \& MOREDA, 1998). However, this process was not necessary for any of the samples analysed.

\subsection{GC/FID analysis}

Capillary chromatography was performed on an HP model 5890 gas chromatograph equipped with an HP model 7673 automatic sampler, a split/splitless injector and a flame-ionisation detector (FID) together with an Agilent ChemStation Plus (all from Agilent, Avondale, PA, USA). Separation was accomplished with an HT-5 (non-polar) capillary column $(25 \mathrm{~m} \times 0.32$ $\mathrm{mm}$ i.d. with $0.1 \mu \mathrm{m}$ film thickness) from SGE Analytical Science (SGE, Austin, TX, USA). The injector temperature was $300{ }^{\circ} \mathrm{C}$; the detector temperature was $300{ }^{\circ} \mathrm{C}$; the oven was programmed to provide $70{ }^{\circ} \mathrm{C}$ changing to $310{ }^{\circ} \mathrm{C}$ at a rate of $5{ }^{\circ} \mathrm{C} \mathrm{min}{ }^{-1}$ and finally holding at $310^{\circ} \mathrm{C}$ for $5 \mathrm{~min}$; splitless injection mode: time $3 \mathrm{~min}$; injection quantity was $1 \mu \mathrm{l}$; GC unit

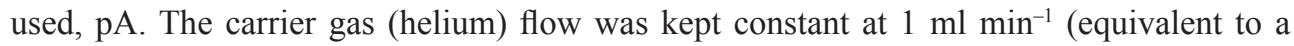
pressure of $52.8 \mathrm{kPa}$ at $\left.50{ }^{\circ} \mathrm{C}\right)$. Nitrogen $\left(30 \mathrm{ml} \mathrm{min}^{-1}\right)$, hydrogen $\left(35 \mathrm{ml} \mathrm{min}^{-1}\right)$ and synthetic air $\left(350 \mathrm{ml} \mathrm{min}^{-1}\right)$ were used as auxiliary gases in the flame ionization detector.

\subsection{GC-MS analysis}

Only for confirmation purposes, GC-MS detection using positive electron ionization was applied for the identification of some compounds. The column (see above) was directly connected to an HP 5988 quadruple MS. The injection temperature was $300{ }^{\circ} \mathrm{C}$ and $1 \mu \mathrm{l}$ of cleaned sample were injected splitless during 3 min, using an HP 7673A automatic sampler (Agilent Technologies, Waldbron, Germany) with an injection port temperature of $290{ }^{\circ} \mathrm{C}$ and transfer line temperature of $300^{\circ} \mathrm{C}$. The following temperature program was used: initial column temperature was held for $1 \mathrm{~min}$ at $70^{\circ} \mathrm{C}$, programmed at $5{ }^{\circ} \mathrm{C} \mathrm{min}{ }^{-1}$ until reaching final temperature of $310^{\circ} \mathrm{C}$, which was held for $5 \mathrm{~min}$. Electron ionization was carried out at $70 \mathrm{eV}$ (filament current $300 \mathrm{~mA}$, electron multiple voltage $1.7 \mathrm{kV}$, preamplifier sensitivity $10^{-7} \mathrm{~A} / \mathrm{V}$ ) with a source temperature of $270{ }^{\circ} \mathrm{C}$ and a scan range of 50-600 mass unit at 2.48 scans $\mathrm{s}^{-1}$ with 5 min of solvent delay. The carrier gas (helium) flow was kept constant at 1.9

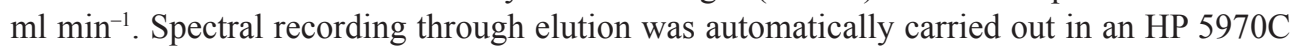
MS Chemstation analytical workstation equipped with mass spectrometric detection in selected ion mode. The concentration of each compound was calculated in $\mathrm{mg} \mathrm{kg}^{-1}$. Diagnostic ions $(\mathrm{m} / \mathrm{z})$ for aliphatic hydrocarbons were: $57,71,85$; for alkylcyclohexanes: 82,83 ; and for hopanes: 191 (AlzAGA et al., 2004). Quantitative result obtained with ion $\mathrm{m} / \mathrm{z} 57$ corresponded to that provided by the response of FID calculated with standard paraffin oil.

\subsection{Validation method}

The total area of the hump, which includes the unresolved MOSH, was integrated by manual positioning of a baseline from the beginning to the end of the hump including the peaks on top. After that, the peaks on top of the hump, that have carbon numbers balanced between even and odd, were integrated using the contour line of the hump as baseline. Finally, the area of the "unresolved complex mixture" (UCM) was deduced from the total area.

The concentration of MOSH was extrapolated from a calibration curve obtained analysing certified $\mathrm{CB}$ spiked with jute batching oil at five different concentrations (between 2 and $600 \mathrm{mg} \mathrm{kg}^{-1}$ ). To avoid interferences, no internal standard was added. The quantitative 
determination of the individual MOSH was based on the integration of the external standard eicosane $\left(n-\mathrm{C}_{20}\right)$. Solutions containing $1,5,10,20,50,100$, and $200 \mu \mathrm{g}$ eicosane in $n$-hexane were prepared. To follow the same process than in the samples, the solvent was evaporated in a rotary evaporator under vacuum at $35^{\circ} \mathrm{C}$. The residue was then solved in $1 \mathrm{ml} n$-hexane to give solutions representing from 1 to $200 \mu \mathrm{g} \mathrm{ml}{ }^{-1}$ and analysed ( $1 \mu \mathrm{lof}$ each solution were injected into the GC system). The standard calibration curve for eicosane was linear in the concentration range of $0-200 \mathrm{mg} \mathrm{kg}^{-1}$. The correlation coefficient value of the standard curve was 0.9998 , calculated from 5 replicates for each concentration. The performance of the procedure was monitored by verification standards composed by $n$-alkanes $\left(\mathrm{C}_{16}\right.$ to $\left.\mathrm{C}_{44}\right)$ at a concentration of $10 \mu \mathrm{g} \mathrm{ml}^{-1}$, and by JBO at a concentration of $50 \mu \mathrm{g} \mathrm{ml}^{-1}$. An aliquot was evaporated to dryness in a rotary evaporator at $35^{\circ} \mathrm{C}$ and analysed (splitless injection). Areas obtained before and after evaporation were evaluated and so investigating the losses of volatile MOSH produced during the evaporation step. The limits of detection (LOD) and quantitation (LOQ) of unresolved MOSH and of individual $n$-alkanes were determined on certified $\mathrm{CB}$, measuring the noise and signal. LOD corresponded to the JBO/individual MOSH amount for which the signal-to-noise ratio of the peaks height was equal to 3 . LOQ corresponded to a signal-to-noise ratio of 6 . The repeatability of the chromatographic separation of some of the components was determined by carrying out five injections of a $\mathrm{CB}$ sample, obtaining the average and standard deviation (SD) computed for each component. The reproducibility was determined by analysing each sample of CB on five different days over one month.

The recoveries of individual $n$-alkanes $\left(\mathrm{C}_{16}\right.$ to $\left.\mathrm{C}_{32}\right)$ were determined on certified $\mathrm{CB}$, containing two levels of concentration, at the limit of quantification (LOQ) and 5 times the LOQ. Five extractions were performed for each concentration, determining the recoveries by comparison with the corresponding concentration curve.

\subsection{Statistical analysis}

Analysis of variance was carried out using Statgraphics Statistical package, version 6.0 (SAS Institute: Cary, NC, USA). Group differences were considered to be statistically significant at a level of $\mathrm{P} \leq 0.05$.

\section{Results and discussion}

\subsection{Analytical method}

The retention time and name of the linear aliphatic MOSH identified in CB are shown in Table 1. The retention time window (RTW) was defined as the average of $\pm 10 \sigma$ (standard deviation) of the retention time of 10 blank samples spiked at the LOQ of each MOSH. The isolation of the MOSH fraction from the fat of the sample has been usually carried out by means of alkaline hydrolysis. A more convenient procedure for an accurate determination of aliphatic MOSH residues in $\mathrm{CB}$ was developed, avoiding the saponification step by adjusting the amount of CB or extract to be loaded in a SPE clean-up cartridge (sep-pak of silica gel). Adsorption chromatography is a well-established procedure to separate aliphatic and polycyclic aromatic hydrocarbons (PAH's), using different adsorbents, such as florisil, silica gel, or alumina (GROB \& ARTHO, 1991; BARRANCO et al., 2003). To obtain optimal conditions for SPE clean-up, several factors were investigated, including the following: type of SPE 
cartridge, washing solvents, eluent solvents, SPE elution volumes for MOSH, and concentration of the extract. Generally, the maximum amount of fat that can be retained depends on the composition and amount of the adsorbent phase, and on the polarity of the eluent. Using the new sep-pak of silica gel $(10 \mathrm{~g} / 60 \mathrm{ml})$, the amount of CB retained $(500 \mathrm{mg})$ was higher than in other methods and sufficient in order to detect JBO at levels of $1 \mathrm{mg} \mathrm{kg}^{-1}$ (LOD) and $2 \mathrm{mg} \mathrm{kg}^{-1}$ (LOQ), without any fat breakthrough (triglycerides) into the chromatographic capillary column. The solvent was also assayed, indicating that the volume recommended was $30 \mathrm{ml}$, because no improvement was observed in a further elution. In accordance with FIORINI and co-workers (2010), the concentration step under rotating evaporator did not modify the concentration of paraffin and the losses from $n-\mathrm{C}_{14}$ onwards were negligible.

The accuracy of the results was determined by the uncertainty of positioning the baseline and the upper contour of the hump. This uncertainty must be estimated for every chromatogram around $25 \%$. The new procedure using SPE clean-up $(10 \mathrm{~g} / 60 \mathrm{ml})$ was validated for the different $n$-paraffins $\left(\mathrm{C}_{16}-\mathrm{C}_{32}\right)$ following the criteria of the European Union 96/23/EC guidelines (EEC, 2002). The results reported in Table 2 show the efficacy of the method: on the one hand, the LOQ varied between 2.0 and $2.2 \mathrm{mg} \mathrm{kg}^{-1}$. On the other hand, the recoveries ranged from 90 and $97 \%$, with RSDs from 5.1 to $7.2 \%$ in terms of intraday precision, and from 6.3 to $7.8 \%$ in terms of interday precision.

Table 1. Linear aliphatic paraffins identified by GC-FID

\begin{tabular}{lcl}
\hline Abbreviation & Retention times (min) & Compound \\
\hline $\mathrm{C}_{16}$ & $13.632 \pm 0.078$ & Hexadecane \\
$\mathrm{C}_{17}$ & $14.857 \pm 0.068$ & Heptadecane \\
$\mathrm{C}_{18}$ & $15.346 \pm 0.073$ & Octadecane \\
$\mathrm{C}_{19}$ & $16.537 \pm 0.071$ & Nonadecane \\
$\mathrm{C}_{20}$ & $18.227 \pm 0.070$ & Eicosane \\
$\mathrm{C}_{21}$ & $19.887 \pm 0.068$ & Heneicosane \\
$\mathrm{C}_{22}$ & $20.707 \pm 0.073$ & Docosane \\
$\mathrm{C}_{23}$ & $22.397 \pm 0.071$ & Tricosane \\
$\mathrm{C}_{24}$ & $24.077 \pm 0.067$ & Tetracosane \\
$\mathrm{C}_{25}$ & $25.757 \pm 0.073$ & Pentacosane \\
$\mathrm{C}_{26}$ & $27.467 \pm 0.072$ & Hexacosane \\
$\mathrm{C}_{27}$ & $29.217 \pm 0.067$ & Heptacosane \\
$\mathrm{C}_{28}$ & $30.887 \pm 0.073$ & Octacosane \\
$\mathrm{C}_{29}$ & $32.607 \pm 0.069$ & Nonocosane \\
$\mathrm{C}_{30}$ & $34.277 \pm 0.075$ & Triacontane \\
$\mathrm{C}_{31}$ & $35.947 \pm 0.068$ & Hentriacontane \\
\hline
\end{tabular}


Table 2. Quantitation limits and recoveries of the main paraffins identified by GC-FID

\begin{tabular}{|c|c|c|c|c|c|c|}
\hline \multirow{2}{*}{\multicolumn{3}{|c|}{ Compound/Limit of quantitation }} & \multicolumn{4}{|c|}{ Mean recovery, $\% \pm \mathrm{RSDs}, \%(\mathrm{n}=5)$} \\
\hline & & & \multicolumn{2}{|c|}{ Repeatability } & \multicolumn{2}{|c|}{ Reproducibility } \\
\hline Peak $n^{\circ}$ & Paraffin & LOQ $\left(\mathrm{mg} \mathrm{kg}^{-1}\right)$ & LOQ & $5 \times \mathrm{LOQ}$ & LOQ & $5 \times \mathrm{LOQ}$ \\
\hline 1 & $\mathrm{C}_{16}$ & 2.0 & $94 \pm 5.8$ & $93 \pm 6.2$ & $92 \pm 6.4$ & $91 \pm 6.8$ \\
\hline 2 & $\mathrm{C}_{18}$ & 2.2 & $95 \pm 5.7$ & $94 \pm 6.3$ & $93 \pm 6.7$ & $92 \pm 7.1$ \\
\hline 3 & $\mathrm{C}_{20}$ & 2.2 & $96 \pm 5.9$ & $95 \pm 6.8$ & $92 \pm 6.3$ & $90 \pm 7.6$ \\
\hline 4 & $\mathrm{C}_{22}$ & 2.0 & $97 \pm 5.1$ & $94 \pm 6.2$ & $93 \pm 6.4$ & $91 \pm 7.4$ \\
\hline 5 & $\mathrm{C}_{24}$ & 2.1 & $96 \pm 6.1$ & $94 \pm 6.4$ & $91 \pm 6.8$ & $90 \pm 7.8$ \\
\hline 6 & $\mathrm{C}_{26}$ & 2.0 & $94 \pm 6.2$ & $93 \pm 6.3$ & $92 \pm 6.9$ & $91 \pm 7.4$ \\
\hline 7 & $\mathrm{C}_{28}$ & 2.2 & $94 \pm 5.9$ & $92 \pm 6.5$ & $92 \pm 6.7$ & $91 \pm 7.2$ \\
\hline 8 & $\mathrm{C}_{30}$ & 2.2 & $93 \pm 6.8$ & $93 \pm 6.2$ & $92 \pm 6.6$ & $90 \pm 6.9$ \\
\hline 9 & $\mathrm{C}_{32}$ & 2.0 & $92 \pm 6.4$ & $91 \pm 7.2$ & $92 \pm 7.2$ & $91 \pm 7.6$ \\
\hline
\end{tabular}

LOQ: Limit of quantitation

\subsection{Mineral oil in cocoa butter and jute bags}

The detection of MOSH in $\mathrm{CB}$ is more and more considerate in order to assure quality and food safety (US FDA, 1987; EFSA, 2012). When analysing these components by GC-FID, the resulting chromatogram presents a hump of unresolved peaks along with natural paraffins (Fig. 2). In general, jute batching oil (JBO) presents the characteristic hump of unresolved components of linear and branched MOSH and the Gaussian shape of the hump reflects the molecular-mass distribution. Table 3 summarizes the mineral oil residues found in jute bags, raw and deodorized CB. Of the 20 jute bags samples analysed belonging to the period 2000 to 2001 , contamination with JBO was reported in $55 \%$ of the samples, forming an unresolved complex mixture (UCM). The UCM presented branched and cyclic $n$-alkanes from $\mathrm{C}_{14}$ to $\mathrm{C}_{22}$, centred on the $n$-alkane $\mathrm{C}_{17}$, and containing from 194 to $484 \mathrm{mg} \mathrm{kg}^{-1}$ (average $253 \mathrm{mg} \mathrm{kg}^{-1}$ ) jute batching oil (UCM), and $n$-alkanes situated on top of the hump between 1021 and 1945 $\mathrm{mg} \mathrm{kg}^{-1}$. Considering the period from 2007 to 2009, the contamination was only detected in the $15 \%$ of the samples analysed, presenting an average total concentration of $148 \mathrm{mg} \mathrm{kg}^{-1}$ JBO (between 125 and $309 \mathrm{mg} \mathrm{kg}^{-1}$ ), with the corresponding concentration of $n$-alkanes between 365 and $987 \mathrm{mg} \mathrm{kg}^{-1}$. Fortunately, the concentration of batching oil detected in jute bags has decreased in the more recent years (reduction 42\%), indicating considerable efforts to replace the mineral oil by food grade oils (IJO, 2005; Dilruba et al., 2010).

Table 3. Jute batching oil residues in cocoa butter and jute bags

\begin{tabular}{lcccc}
\hline Product & $\begin{array}{c}\text { Number of } \\
\text { samples }\end{array}$ & $\begin{array}{c}\text { Samples with } \\
\text { UCM }\end{array}$ & $\begin{array}{c}\text { UCM }\left(\mathrm{mg} \mathrm{kg}^{-1}\right) \\
\text { average }(\mathrm{min}-\mathrm{max})\end{array}$ & $\begin{array}{c}n \text {-Alkanes }\left(\mathrm{C}_{14}-\mathrm{C}_{22}\right)\left(\mathrm{mg} \mathrm{kg}^{-1}\right) \\
\text { average }\left(\min -\mathrm{max}^{2}\right)\end{array}$ \\
\hline Raw cocoa butter & 40 & $8(20 \%)$ & $42(14-47)^{\mathrm{a}}$ & $51(32-72)^{\mathrm{a}}$ \\
Deodorized cocoa butter & 40 & $3(7.5 \%)$ & $22(15-36)^{\mathrm{b}}$ & $2.6(2.1-3.1)^{\mathrm{b}}$ \\
Jute bags & 20 & $11(55 \%)^{\mathrm{a}}$ & $253(194-484)^{\mathrm{a}}$ & $1387(1021-1945)^{\mathrm{a}}$ \\
& 20 & $3(15 \%)^{\mathrm{b}}$ & $148(125-309)^{\mathrm{b}}$ & $739(365-987)^{\mathrm{b}}$ \\
\hline
\end{tabular}

UCM: Unresolved complex mixture; ${ }^{\text {a: }}$ period 2000 to 2001 ; ${ }^{\text {b: period }} 2007$ to 2009 
Table 4. Distribution of paraffin residues $\left(\mathrm{mg} \mathrm{kg}^{-1}\right)$ in contaminated jute bags and raw cocoa butter samples from 2000 to 2001

\begin{tabular}{lccc}
\hline Paraffin & Average & Vmin & Vmax \\
\hline $\mathrm{C}_{14}$ & $68 / 6$ & $48 / 2$ & $147 / 7$ \\
$\mathrm{C}_{15}$ & $316 / 17$ & $298 / 14$ & $487 / 24$ \\
$\mathrm{C}_{16}$ & $225 / 13$ & $153 / 9$ & $311 / 16$ \\
$\mathrm{C}_{17}$ & $314 / 14$ & $217 / 11$ & $421 / 19$ \\
$\mathrm{C}_{18}$ & $189 / 7$ & $142 / 5$ & $244 / 11$ \\
$\mathrm{C}_{19}$ & $142 / 6$ & $119 / 4$ & $198 / 9$ \\
$\mathrm{C}_{20}$ & $93 / 4$ & $41 / 2$ & $130 / 5$ \\
$\mathrm{C}_{21}$ & $38 / \mathrm{ND}$ & $21 / \mathrm{ND}$ & $75 / 3$ \\
$\mathrm{C}_{22}$ & $18 / \mathrm{ND}$ & $12 / \mathrm{ND}$ & $47 / 2$ \\
Total & $1387 / 51$ & $1021 / 32$ & $1945 / 72$ \\
\hline
\end{tabular}

Contaminated jute bags samples ( $n=11)$; contaminated raw cocoa butter samples $(n=8)$; left value: jute bags; right value: raw cocoa butter; ND: not detected $\left(<2 \mathrm{mg} \mathrm{kg}^{-1}\right)$

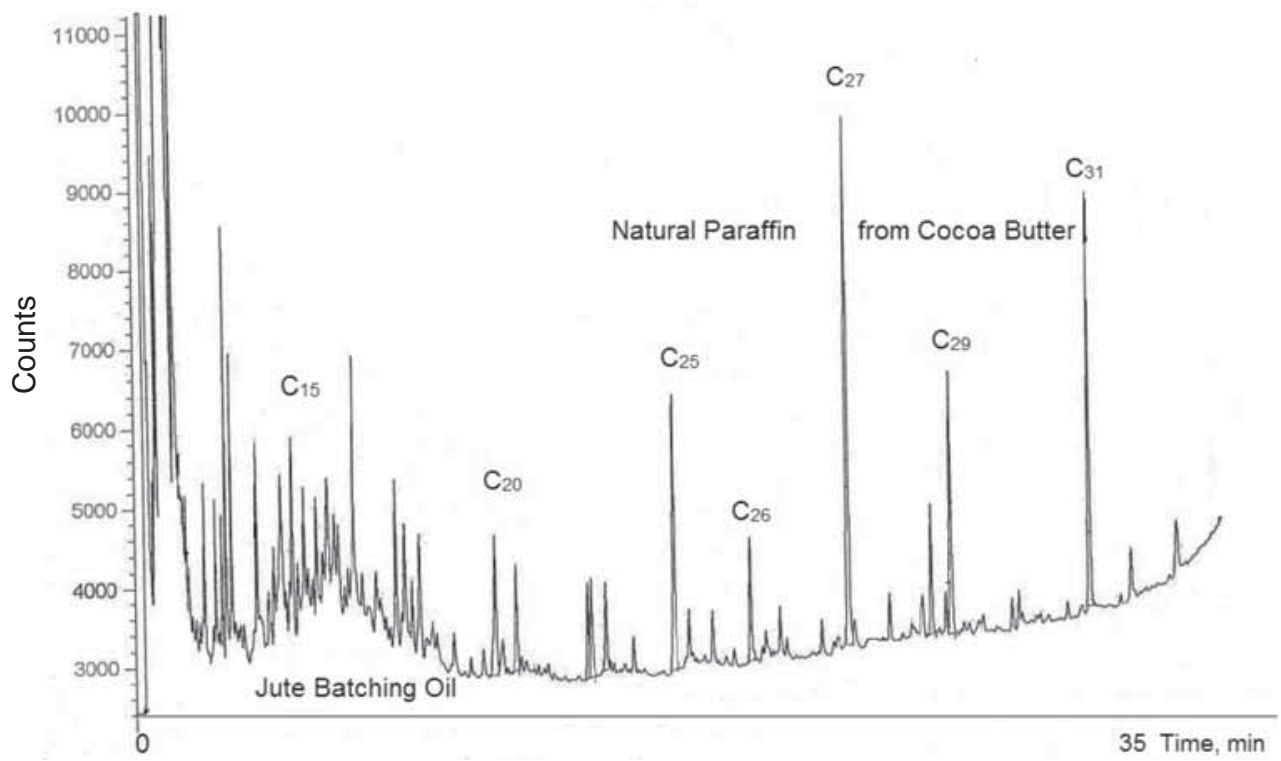

Fig. 2. GC/FID chromatogram of raw cocoa butter contaminated with jute batching oil

JOB residues were detected in 8 of the 40 samples of raw $\mathrm{CB}$, at concentrations of JBO from 14 to $47 \mathrm{mg} \mathrm{kg}^{-1}$ and $n$-alkanes between 32 and $72 \mathrm{mg} \mathrm{kg}^{-1}$, during the period from 2000 to 2001 (Table 3). The fact that all the contaminated samples presented a hump of unresolved even and odd-numbered $n$-alkanes, with the same molecular-mass distribution that those 
identified in jute bags, was valid to differentiate pure CB from contaminated CB (Tables 3 and 4). However, the sequence of detected components could be slightly different, depending on the source of the mineral oil and the processes applied in their production. Today, contamination of deodorized $\mathrm{CB}$ with JBO can be determined very sensitively by the detection of mineral paraffin components or other compounds not characteristic of pure $\mathrm{CB}$. The low-molecular mass components below $n-\mathrm{C}_{20}$ were totally eliminated after raffination, in particular deodorization of CB. During the period from 2007 to 2009 the contamination was lower than those of the previous years (Tables 3 and 5). The contamination was only detected in 3 of $40 \mathrm{CB}$ commercial samples extracted from African cocoa beans. The results ranged from 15 to $36 \mathrm{mg} \mathrm{kg}^{-1} \mathrm{JBO}\left(\mathrm{UCM}\right.$ ) accompanied by natural $n$-alkanes from $\mathrm{C}_{22}$ to $\mathrm{C}_{31}$ (at concentrations between 21.8 and $56.7 \mathrm{mg} \mathrm{kg}^{-1}$ ) (Table 5). Although the contaminant substance had been the same, these results indicated that the use of contaminated jute bags started to be under control, and so was the migration of JBO into CB.

Table 5. Distribution of mineral oil and natural paraffins $\left(\mathrm{mg} \mathrm{kg}^{-1}\right)$ in contaminated jute bags and deodorized cocoa butter samples from 2007 to 2009

\begin{tabular}{lccc}
\hline Paraffin & Average & Vmin & Vmax \\
\hline $\mathrm{C}_{14}$ & $60 / \mathrm{ND}$ & $48 / \mathrm{ND}$ & $109 / \mathrm{ND}$ \\
$\mathrm{C}_{15}$ & $73 / \mathrm{ND}$ & $50 / \mathrm{ND}$ & $116 / \mathrm{ND}$ \\
$\mathrm{C}_{16}$ & $89 / \mathrm{ND}$ & $54 / \mathrm{ND}$ & $126 / \mathrm{ND}$ \\
$\mathrm{C}_{17}$ & $97 / \mathrm{ND}$ & $58 / \mathrm{ND}$ & $133 / \mathrm{ND}$ \\
$\mathrm{C}_{18}$ & $92 / \mathrm{ND}$ & $56 / \mathrm{ND}$ & $128 / \mathrm{ND}$ \\
$\mathrm{C}_{19}$ & $81 / \mathrm{ND}$ & $55 / \mathrm{ND}$ & $122 / \mathrm{ND}$ \\
$\mathrm{C}_{20}$ & $73 / \mathrm{ND}$ & $53 / \mathrm{ND}$ & $113 / \mathrm{ND}$ \\
$\mathrm{C}_{21}$ & $65 / \mathrm{ND}$ & $47 / \mathrm{ND}$ & $104 / \mathrm{ND}$ \\
$\mathrm{C}_{22}$ & $46 / 2.6$ & $38 / 2.1$ & $84 / 3.1$ \\
$\mathrm{C}_{23}$ & $-/ 4.4$ & $-/ 2.5$ & $-/ 5.9$ \\
$\mathrm{C}_{24}$ & $-/ 2.5$ & $-/ 2.1$ & $-/ 4.1$ \\
$\mathrm{C}_{25}$ & $-/ 5.4$ & $-/ 4.2$ & $-/ 8.4$ \\
$\mathrm{C}_{26}$ & $-/ 2.8$ & $-/ 2.2$ & $-/ 3.9$ \\
$\mathrm{C}_{27}$ & $-/ 4.9$ & $-/ 3.3$ & $-/ 8.7$ \\
$\mathrm{C}_{28}$ & $-/ 3.4$ & $-/ 2.6$ & $-/ 4.1$ \\
$\mathrm{C}_{29}$ & $-/ 3.6$ & $-/ 2.2$ & $-/ 5.9$ \\
$\mathrm{C}_{30}$ & $-/ 2.5$ & $-/ 2.0$ & $-/ 4.3$ \\
$\mathrm{C}_{31}$ & $-/ 3.6$ & $-/ 2.8$ & $-/ 6.3$ \\
Total $_{2}$ & $739 / 33.1$ & $365 / 21.8$ & $987 / 56.7$ \\
$\mathrm{CPI}$ & $0.86 / 1.46^{*}$ & $0.71 / 1.26^{*}$ & $1.04 / 1.96 *$ \\
\hline & & &
\end{tabular}

$\mathrm{C}_{22}$ to $\mathrm{C}_{31}$ natural $n$-alkanes; ND: not detected $\left(<2 \mathrm{mg} \mathrm{kg}^{-1}\right)$; CPI: carbon preference index; (-): absence of component; contaminated jute bags samples $(n=3)$; contaminated deodorized cocoa butter samples $(n=3)$; left value: jute bags; right value: deodorized cocoa butter; *: on natural paraffins 
Table 6. Natural paraffins identified in deodorized cocoa butter $\left(\mathrm{mg} \mathrm{kg}^{-1}\right)$

\begin{tabular}{lccc}
\hline Paraffin & Average & Vmin & Vmax \\
\hline $\mathrm{C}_{22}$ & 2.8 & 2.1 & 5.8 \\
$\mathrm{C}_{23}$ & 4.1 & 3.7 & 7.2 \\
$\mathrm{C}_{24}$ & 2.9 & 2.2 & 6.3 \\
$\mathrm{C}_{25}$ & 4.9 & 4.1 & 11.2 \\
$\mathrm{C}_{26}$ & 2.5 & 2.0 & 6.3 \\
$\mathrm{C}_{27}$ & 5.4 & 4.5 & 13.3 \\
$\mathrm{C}_{28}$ & 2.6 & 2.1 & 4.9 \\
$\mathrm{C}_{29}$ & 3.8 & 2.6 & 7.5 \\
$\mathrm{C}_{30}$ & 2.7 & 2.2 & 5.2 \\
$\mathrm{C}_{31}$ & 3.6 & 2.8 & 7.3 \\
Total & $31.7 \pm 5.37$ & 23.9 & 61.4 \\
$\mathrm{CPI}$ & 1.39 & 1.28 & 1.84 \\
\hline
\end{tabular}

$\mathrm{n}=40$ samples; $C P I$ : carbon preference index

Commercial CB was characterized by the presence of a mixture of natural saturated and unsaturated paraffins (situated between $\mathrm{C}_{22}$ and $\mathrm{C}_{31}$ ), with a strong predominance of the oddnumbered $n$-alkanes, which have the maximum values usually at $\mathrm{C}_{25}$ or $\mathrm{C}_{27}$. Olefins $n$ - $\mathrm{C}_{25}$, $\mathrm{C}_{27}, \mathrm{C}_{29}$, and $\mathrm{C}_{31}$, were identified in minimal concentration ( $<\mathrm{LOQ}$ ). Total alkanes have been reported such as major components of $\mathrm{CB}$, with a total concentration of $31.7 \pm 5.37 \mathrm{mg} \mathrm{kg}^{-1}$, in conformity with the mean values and ranges obtained in contaminated CB (Tables 5 and 6 ). Our data showed that the deodorization process affected the concentration of mineral MOSH, removing the more volatile components below $n$-alkane $\mathrm{C}_{20}$. This affirmation is in line with similar investigations carried out in other vegetable oils and fats (WAGNER et al., 2001a; FIORINI et al., 2008). The analysis of variance indicated significant differences $(\mathrm{P} \leq 0.05)$ between $\mathrm{CB}$ of different origins (Brazil and African provenance). Saturated $n$-alkanes with odd number of carbon atoms situated between $\mathrm{C}_{22}$ and $\mathrm{C}_{31} n$-alkanes were more abundant in natural $\mathrm{CB}$, which presented a calculated CPI average value of 1.39 (Table 6). High CPI values $(>1.26)$ were related to high content of natural paraffins, while values lesser than 1.05 could indicate greater input from mineral $n$-alkanes situated on top of the hump (Table 5). A maximum allowable limit for mineral oil (MOSH) in $\mathrm{CB}$ has not been set by European Union Commission yet. But, in June 2008, the EU Commission specified a legal limit of 50 $\mathrm{mg} \mathrm{kg}^{-1}$ for mineral paraffins in Ukrainian crude and refined sunflower oils (SCFCAH, 2008). The lack of some more strict regulations and the results of this work led us to suggest to the manufacturers to establish a periodic monitoring programme on MOSH detection to assure the food safety of $\mathrm{CB}$, and what is more, considering that the contaminated $\mathrm{CB}$ may also contain a wide profile of other HC's, such as alkylated aromatic of 1-6 rings, to extend the control to these compounds, too (ZiEgEnhals et al., 2009).

\section{Conclusions}

The presence of MOSH in CB was directly related to jute batching oil (JBO) when cocoa beans were transported and stored in jute bags. The contamination was characterized by the 
presence of numerous hydrocarbons on an unresolved Gaussian shape background (hump) from $\mathrm{C}_{14}$ to $\mathrm{C}_{22} n$-alkanes, centred on the $n$-alkane $\mathrm{C}_{17}$ with $\mathrm{CPI}$ value $<1.05$. Deodorized cocoa butter exhibited lower presence of JBO $\left(<36 \mathrm{mg} \mathrm{kg}^{-1}\right)$, eliminating all the paraffins below $n$ - $\mathrm{C}_{20}$. Uncontaminated $\mathrm{CB}$ showed natural $n$-paraffins $\left(\mathrm{C}_{22}\right.$ to $\left.\mathrm{C}_{31}\right)$ at concentrations between 22 and $62 \mathrm{mg} \mathrm{kg}^{-1}$. A periodic monitoring programme on cocoa beans to detect MOSH has been recommended to assure the food safety of CB.

\section{References}

Alzaga, R., Montuori, P., Ortiz, L., Bayona, J.M.\&Albaigés, J. (2004): Fast solid-phase extraction-gas chromatography-mass spectrometry procedure for oil fingerprinting. Application to the Prestige oil spill. J. Chromat. A, 1025, 133-138.

Barranco, A., Alonso-Salces, R.M., Berrueta, I.A., Gallo, B., Vicente, F.\& Sarobe, M. (2003): Comparison of two sample clean-up methodologies for the determination of polycyclic aromatic hydrocarbons in hydrocarbons in edible oils. J. Sep. Sci., 26, 1554-1562.

Bastow, T.P., Aarsse, B.G.K.\& LAmG, D. (2007): Rapid small-scale separation of saturate, aromatic and polar components in petroleum. Org. Geochem., 38, 1235-1250.

Biedermann, M.\& Grob, K. (2009): How "white" was the mineral oil in the contaminated Ukranian sunflower oils? Eur. J. Lipid. Sci. Technol., 111, 313-319.

Cert, A. \& Moreda, W. (1998): New method of stacionary phase preparation for silver ion column chromatography: Application to the isolation of steroidal hydrocarbons in vegetable oils. J. Chromat.. A, 823, 291-297.

Dilruba, F.A., Amin, M.N., Molla, M.E., Rahman, S.M.B.\& Jafrin, S. (2010): Production of jute yarns with low content of unsaponifiable matters. Daffodil Int. Univ. J. Sci. \& Technol., 3, 10-18.

Droz, Ch. \& Grob, K. (1997): Determination of food contamination by mineral oil material from printed cardboard using on-line coupled LC-GC-FID. Z. Lebensm. Unters. Forsch. A, 205, 239-241.

EEC (2002): Commission decision 96/23/EC, August 12, 2002, concerning the performance of analytical methods and the interpretation of results. Off. J. Eur. Commun., L 221/8, 8-36.

EFSA (2012): Scientific opinion on mineral oil hydrocarbon in food. EFSA panel on contaminants in the food chain (CONTAM). European Food Safety Authority, EFSA J., 10, 2704, 185 pages.

Fiorini, D., Fiseler, K., Biedermann, M., Ballini, R., Coni, E.\& Grob, K. (2008): Contamination of grape seed oil with mineral oil paraffins. J. Agric. Fd Chem., 56, 11245-11250.

Fiorini, D., Paciaroni, A., Gigli, F. \& Ballini, R. (2010): A versatile splitless injection GC-FID method for the determination of mineral oil paraffins in vegetable oils and dried fruit. Fd Control, 21, 1155-1160.

Fiseler, K. \& GRoB, K. (2009): Determination of mineral oil paraffins in foods by on-line HPLC-CG-FID: lowered detection limit; contamination of sunflower seeds and oils. Eur. Fd Res. Technol., 229, 679-688.

Grob, K.\& Artho, A. (1991): Coupled LC-GC: The capacity of silica gel (HP)LC columns for retaining fat. J. High Resol. Chromat., 14, 373-376.

Grob, K., Lanfranchi, M., Egli, J.\&Artho, A. (1991): Determination of food contamination by mineral oil from jute sacks using coupled LC-GC. J. Assoc. Off. Anal. Chem., 74, 506-512.

Grob, K., Artho, A., Biedermann, M.\& Caramaschi, A. (1992): Batching oils on sisal bags used for packaging foods: analysis by coupled LC/GC. J. Assoc. Off. Anal. Chem., 75, 283-287.

Gryna, F., Chua, R., Defeo, J., Chua Ricard, C.H.\& Defeo, J.A. (2005): Juran's quality planning and analysis for enterprise quality. Mc-Graw-Hill Series in Industrial Engineering and Management Science, $5^{\text {th }}$ ed., New York, 774 pages.

IJO (2005): IJO Standard 98/01, International Jute Study Group, Dhaka, Bangladesh, Revised 2005.

JECFA (1995): Summary of evaluations performed by the Joint FAO/WHO Expert Committee on Food Additives. $<$ http://www.inchem.org/documents/jecfa/jeceval/jec_1655.htm>

LipP, M. \&ANKLAM, E. (1998): Review of cocoa butter and alternative fats for use in Chocolate - Part A. Composition data. Fd Chem., 62, 73-97.

McGill, A.S., Moffat, C.F., Mackie, P.R. \& CRuikshank, P. (1993): The composition and concentration of $n$-alkanes in retail samples of edible oils. J. Sci. Fd Agric., 61, 357-362.

Moret, S., Populin, T., Conte, L.S., Grob, K.\&Neukom, H.P. (2003): Occurrence of $\mathrm{C}_{15}-\mathrm{C}_{45}$ mineral paraffins in olives and olive oils. Fd Addit. Contam., 20, 417-426. 
Populin, T., Biedermann, M., Grob, K., Moret, S.\& Conte, L. (2004): Relative hopane content confirming the mineral origin of hydrocarbons contaminating foods and human milk. Fd Addit. Contam., 21, 893-904.

SCFCAH (2008): Summary minutes of the meeting of the Standing Committee on the Food Chain and Animal Health, Brussels, 28 Jun 2008. http://e.europa.eu/food/committees/regulatory/scfcah/toxic/summary20062008

Tennant, A.R. (2004): The usage, occurrence and dietary intakes of white mineral oils and waxes in Europe. Fd Chem. Toxicol., 42, 481-492.

US FDA (1987): The Code of Federal Regulations, 21 CFR 172.878 White mineral oil for direct food contact. National Archives and Records Administration, Washington, DC.

Volkman, J.K., Holdsworth, D.G., Neill, G.P.\& Bavor, H.J. (1992): Identification of natural, anthropogenic and petroleum hydrocarbons in aquatic sediments. Sci. Total Environ., 112, 203-219.

Wagner, Ch., Neukom, H.P.\& Grob, K. (2001a): Mineral paraffins in vegetable oils and refinery by-products for animal feeds. Mitt. Lebensm. Hyg., 92, 499-514.

Wagner, Ch., Neukom H.P., Galetti, V.\&Grob, K. (2001b): Determination of mineral paraffins in feeds and foodstuffs by bromination and preseparation on aluminium oxide: methods and results of a ring test. Mitt. Lebensm. Hyg., 92, 231-249.

Ziegenhals, K., Speer, K.\& Jira, W. (2009): Polycyclic aromatic hydrocarbons (PAH) in chocolate on the German market. J. Verbrauch. Lebensm., 4, 128-135. 